13. Marchenko O. \& Pohrishchuk H. (2009). Finansovyi stan pidpryiemstva ta napriamky yoho zmitsnennia [Financial condition of the enterprise and directions of its strengthening] Svit finansiv - The world of finance, 4 (21), 135 - 146 [in Ukraine].

Стаття надійшла до редакції 20.08.2019 р.

УДК 657.6(0.02)-047.44

Melnyk Katerina,

PhD in Economics, Associate Professor,

Lesia Ukrainka Eastern Europen National University,

Department of Accounting and Audit

Luck; ORCID ID 0000-0001-9167-5801

e-mail: pristypakatia@ukr.net

https://doi.org/10.29038/2411-4014-2019-03-143-148

\title{
TRANSFORMATION OF AUDIT PROCEDURES IN A CONTEXT OF DECENTRALIZATION
}

\begin{abstract}
The research has an applied character. For the achievement of its aim scientific (abstraction, analysis, synthesis, induction, deduction) and specialized (bibliographic analysis, systemic analysis, economic and legal analysis, generalization and grouping and others like that) methodical approaches were used.

It is concluded that decentralization is accompanied by a redistribution of plenary powers between the subjects of management, necessary for the implementation of their resources as well as responsibility. It is substantiated that the processes of decentralization can result in the redistribution of plenary powers between state and independent auditors as a result of changes in expectations of initiators of audit and users of its results. Direct and mediated influence of decentralization on the elements of audit as tasks from a grant to the confidence to the users of its results is identified.

The results of the research, independently conducted by the author, expounded in the article are characterized of scientific novelty. In particular, influence of processes of decentralization on functioning of state and independent audit is first identified. The received results will facilitate the optimization of the use of information by economic entities on the basis of providing of high level of credibility to it from the side of users taking into account the confidence given on results of an audit.
\end{abstract}

Key words: information, audit, decentralization, state audit, public control, management system.

Мельник Екатерина, кандидат экономических наук, доцент, Восточноевропейский национальный университет имени Леси Украинки, кафедра учета и аудита

\section{ТРАНСФОРМАЦИЯ АУДИТОРСКИХ ПРОЦЕДУР В КОНТЕКСТЕ ДЕЦЕНТРАЛИЗАЦИИ}

Аннотация. Исследование имеет прикладной характер. Для достижения его цели были использованы общенаучные (абстрагирование, анализ, синтез, индукция, дедукция) и специализированные (библиографический анализ, системный анализ, экономико-правовой анализ, обобщение и группировка т.д.) методические приемы.

Установлено, что децентрализация сопровождается перераспределением между субъектами управления полномочий, необходимых для их реализации ресурсов, а также ответственности. Обосновано, что процессы децентрализации могут привести к перераспределению полномочий между государственными и независимыми аудиторами в результате изменения ожиданий инициаторов аудита и пользователей его результатов. 
Идентифицировано непосредственное и опосредованное влияние децентрализации на элементы аудита как задача по предоставлению уверенности пользователям его результатов.

Ключевые слова: информация, аудит, децентрализация, государственный аудит, публичный контроль, управленческая система.

Мельник Катерина, кандидат економічних наук, доцент, Східноєвропейський національний університет імені Лесі Українки, кафедра обліку і аудиту

\section{ТРАНСФОРМАЦІЯ ПРОЦЕДУР АУДИТУ В УМОВАХ ДЕЦЕНТРАЛІЗАЦЇ̈}

Анотація. Метою дослідження, результати якого розкриваються у цій статті, є перевірка гіпотези щодо існування впливу децентралізації економічних процесів на функціонування аудиту як однієї з форм контролю, а також ідентифікація та формалізація його характеристик. Дослідження має прикладний характер. Для досягнення його мети були використані загальнонаукові (абстрагування, аналіз, синтез, індукція, дедукція) та спеціалізовані (бібліографічний аналіз, системний аналіз, економіко-правовий аналіз, узагальнення та групування тощо) методичні прийоми.

Встановлено, що децентралізація супроводжується перерозподілом між суб'єктами управління повноважень, необхідних для їх реалізації ресурсів, а також відповідальності. Обгрунтовано, що процеси децентралізації можуть призвести до перерозподілу повноважень між державними і незалежними аудиторами внаслідок зміни очікувань ініціаторів аудиту та користувачів його результатів. Ідентифіковано безпосередній та опосередкований вплив децентралізації на елементи аудиту як завдання з надання впевненості користувачам його результатів.

Результати проведеного дослідження мають теоретичне і практичне значення. Результати самостійно проведеного автором дослідження, викладені у статті, характеризуються науковою новизною. Зокрема, вперше ідентифікований вплив процесів децентралізації на функціонування державного і незалежного аудиту. Отримані результати сприятимуть оптимізації використання інформації економічними суб'єктами на основі забезпечення високого рівня довіри до неї з боку користувачів 3 урахуванням упевненості, наданої за наслідками аудиту.

Ключові слова: інформація, аудит, децентралізація, державний аудит, публічний контроль, управлінська система.

Formulation of the problem. A feature of the audit as a form of control, the results of which users authenticated information provides confidence, there is a need to obtain appropriate audit evidence extent which is sufficient for forming the auditors opinion. Thus, the appropriateness and sufficiency of audit evidence is their characteristics that can be determined, depending on the subject of the audit or the requirements of normative legal documents (for the subjects of the state audit) or through the application of professional judgment (independent auditors).

The public sector and the independent audit in the context of decentralization can vary depending on the content and nature of delegated legislation and/or users of the information authority. In spite of this, are subject to change and approaches to obtaining and evaluating audit evidence.

Exactly necessity of determination and scientific ground of fact and character of influence of decentralization on procedures of audit, that a public accountant can use, and stipulates actuality of research the separate results of that are expounded in the real article.

The analysis of researches and publications. The analysis of publications of foreign and home scientists grounds to establish, that functioning of audit in the conditions of decentralization confesses researchers as an independent object of research. In particular, question of determination of corresponding terminology, authentication of requirements of subjects of audit to information, determination of his influence on economic activity and on information that is used by the different groups of economic subjects expose in scientific publications R. Akoff, S. Bardash, Yu. Bezdushna, O. Viliamson, V. Vorobei, E. Holovanov, V. Derii, V. Zhuk, I. Zhurovska, D. Nort, T. Osadcha, S. Savchenko, O. Sokil, O. Cherevkoand other. 
Not casting aside scientific achievements got home and foreign scientists and practitioners, expedient is a necessity to mark the insufficient level of scientific decision of problem of authentication of necessities of users of results of audit in the conditions of decentralization. In particular, to our opinion, in scientific and professional publications there are the described not enough features of maintenance of factors under act of that expectations of users of results of audit are formed, and a direct algorithm needs clarification forming of criteria, after that information that is subject can be estimated audit.

The purpose of the work. Having regard to the stated, formalization of transformation processes is certain the aim of research the results of that are expounded in the article in an audit in the conditions of decentralization. Coming from it, by the tasks of corresponding research certainly: authentication of necessities of different groups of users of information in the process of audit; determination of maintenance of possible influence of subjects of audit on forming of him informative environment.

Presentation of the main research material. So, if decentralized individual tasks evaluation of information in the interests of its users conducted by an independent auditor, for the purpose of evaluation of relevant data it is mostly used means of obtaining, processing and evaluating audit evidence, the content of which was determined by the requirements of normative documents. In particular, it relates to a mandatory inventory of assets, counter check transactions associated with the characterization of the object of taxation, application of a continuous approach to the verification of the cash transactions.

At the same time, regulatory documents provided and effectiveness of individual audit procedures. In accordance with the requirements of the International standards of control of quality, audit, review, other grant to the confidence and concomitant services [1] an audit is one of types of tasks from a grant to the confidence to the users of information. Thus, among the signs of authentication of such tasks the presence of criteria after that information can be appraised during realization of audit is distinguished exactly. Despite the relevant requirements of the current legislation, the subject of the state is experiencing lower audit risks associated with the possibility of access to individual documents or answers to written or verbal requests.

However, the state auditor obtained audit evidence is the basis not only for the formation of professional judgment as to the statement of facts of the presence or absence of abnormalities in the activity of object of control. In the future, identification of any deviations during audit of the state is regarded, not as a sign of deliberate (fraud) or unintentional (error) personnel actions under the control of the object, and as a basis for future identification of the responsible persons and the qualification of their actions (or inactions!) in the context of application of legislation on administrative and criminal responsibility.

But, the content, volume and assessment of the characteristics of audit evidence obtained, the independent auditor shall be determined solely on the basis of his professional judgment. In this regard, the risks of the independent auditor related to the probability of not receiving responses to requests or restrictions on access to information, will be higher estimated value than for the state auditor. It is also worth noting that the audit evidence obtained by the independent auditor, directly affect his professional judgment in respect of the information which has to be checked. But any identified deviations are evaluated by the auditor as signs of offences, and as evidence of deficiencies which may have an impact on the accuracy of verified information or on its conformity to established requirements regarding the presentation to users.

In a context marked, the point of view ofdeserves attention Sherstiuk O. L. that suggests to define casual, base, having a special purpose, evaluation and functional levels of consumer behavior of users of financial information. Data undertaken a study allowed to the author to come to the conclusion that "going near authentication of consumer behavior of users of financial information give an opportunity to estimate the culture of consumption of financial information, on that the estimation of expectations of users will depend both from information and from the results of her audit, and also is maintenance of tasks that can be certain on the stage of acceptance of decisions a public accountant in relation to a collaboration with the customer of audit, and degree confidence, that can be expounded public accountant" [2, p. 44].

Describe features of audit evidence collected by the state and the independent auditors do not change their nature, content or assessment characteristics in the context of decentralization of economic relations. However, in the case where there is a redistribution of the powers of the entities responsible for the preparation of information and its user, changing only the procedure of obtaining and evaluating audit evidence, which is a consequence of the delegation of the ability of audit clients to decide on changes to the state auditor on an independent and other. 
On the basis of the got public accountant proofs and results of their evaluation, public accountants formalize conducted job performances from the evaluation of activity of control object and information on her. However, coming from divergences in plenary powers of state and independent public accountants, it is possible to establish to divergence in their job performances. In particular, it touches the method of formalization of results of audit.

A report contains on results realization of state audit, first of all, establishment of the actually educed disparities, that, in most cases, have a normatively-legal ground. In other words, identified by the state public accountant of rejection in information examined from the point of view of exposure of possible violation of legislation. Thus, a job of state public accountant performance is characterized by the unambiguity of exposition, does not envisage application of warning that can become the consequence of mix-up of public accountant with maintenance of information and her limitation. The marked is stipulated by absence in-process state public accountant of risk oriented methodology of evaluation of information, that, in particular, envisages the evaluation of level of her importance for the further evaluation of the educed rejections. The same touches and to absence of necessity to determine during formalization of results of audit of influence on the public accountant estimation of limitations in access to information that must be tested, as probability of such fact in a state audit is not examined.

At the same time, implementation of tasks of independent audit is base on wideuse of evaluation judgements of public accountant on the basis of confession of probability of not exposure of substantial rejections. In the context of marked, an independent public accountant during forming of public accountant report acknowledges possibility of partial or complete mix-up with maintenance and descriptions, by the given to the tested information persons accountable for her preparation. Thus, an independent public accountant admits possibility of both the access restriction to information that must be tested and influence of such limit on information and on own judgement in relation to her.

Having regard to it, divergences take place in the methods of drawing on the results of audit. The results of independent audit contain a subjective estimation the public accountant of the educed facts, that envisages offering an own opinion only. Interpretation of such idea too has subjective character the users of the tested data, as it is base on judgements of corresponding personnel. Thus, except for the certain decisions of users, on results, the stated in the report of independent public accountant, professional responsibility of persons accountable for activity of control object and for her results comes, as a rule. An order is removals of defects, that were taken into account by an external public accountant during formalization of the opinion, it is determined directly by a subject accountable for preparation of information.

However, on results a state audit the users of the tested information can be made decision in relation to bringing in of responsible persons to administrative and criminal responsibility, and also - in relation to application of approvals in relation to the subject of menage. Thus, exactly users determine the order of removal of the disparities educed during a state audit, and apply the approvals envisaged by a current legislation.

As in the case of receipt and evaluation of public accountant proofs, forming of public accountant report in the conditions of decentralization will purchase no rich in content changes.

At the same time, a presence or absence of such changes will be determined by character and maintenance of plenary powers in relation to initiation of realization of audit of activity or information about her consequences and, accordingly, in relation to a subject that can be brought over to realization of audit.

In the context of providing of the effective use of possibilities of development, Kocherha M. M. marks that "for determination of efficiency of the use of those or other resources it is necessary to know them cost equivalent, it is needed to carry out their evaluation. Realization of the put task envisages the complex of measures and long-term prognostication of the use of naturally-resource potential taking into account cooperating with a world economy" [3, p. 30].

Depending on the redistribution of plenary powers, resources and responsibility between the subjects of control system as a result of decentralization will change and their interests and, as a result, informative necessities test transformation. It is marked, on our persuasion, will have an influence on rich in content descriptions of the article of audit as another element of task on results implementation of that to the users of information the certain level of confidence is given. Having regard to it, expectations of users of job of public accountant performances will change, and thus - and method of their authentication and formalization. 
To our opinion, influence of decentralization on relations between the participants of the system of audit and on authentication of his object has direct character, as determined exactly by the terms of decentralization.

But, influence of decentralization on other elements of audit as a task on results implementation of that a confidence is given to the users consists only in the redistribution of functions between a state and independent audit.

The results of authentication of influence of decentralization on a state and independent audit are expounded in a table. 1.

Table 1

Description of influence of decentralization is on an audit*

\begin{tabular}{|l|l|l|}
\hline \multirow{2}{*}{ Element of audit } & \multicolumn{3}{|c|}{ Description of influence on } \\
\cline { 2 - 3 } $\begin{array}{l}\text { Presence of three participants of } \\
\text { relations }\end{array}$ & $\begin{array}{l}\text { Influence is direct. It is } \\
\text { determined by the redistribution } \\
\text { of plenary powers, resources and } \\
\text { spheres of responsibility in a } \\
\text { public sector and in the field of } \\
\text { the use of state resources. }\end{array}$ & $\begin{array}{l}\text { Influence is direct. It is } \\
\text { determined by the redistribution } \\
\text { of plenary powers, resources and } \\
\text { spheres of responsibility in a } \\
\text { private sector and in the field of } \\
\text { the use of private resources. }\end{array}$ \\
\hline Article of audit & $\begin{array}{l}\text { Influence is direct. It is } \\
\text { determined by expectations of } \\
\text { users of information on the use of } \\
\text { state resources. }\end{array}$ & $\begin{array}{l}\text { Influence is direct. It is } \\
\text { determined by expectations of } \\
\text { users of information on the use of } \\
\text { private resources. }\end{array}$ \\
\hline $\begin{array}{l}\text { Choice of criteria of evaluation of } \\
\text { object }\end{array}$ & $\begin{array}{l}\text { Influence is indirect. It is } \\
\text { determined by the redistribution } \\
\text { of plenary powers between the } \\
\text { state and independent subjects of } \\
\text { auditin the field of the evaluation } \\
\text { of the use of state resources. }\end{array}$ & $\begin{array}{l}\text { Influence is indirect. It is } \\
\text { determined by the redistribution } \\
\text { of plenary powers between the } \\
\text { state and independent subjects of } \\
\text { audit in the field of the evaluation } \\
\text { of the use of private resources. }\end{array}$ \\
\hline Results of audit
\end{tabular}

*Source: development of author

Conclusions from the research. It costs to mark that other factor of changes in behavior of economic subjects are changes in descriptions of information, on the basis of that made decision, realization of that assists the achievement of corresponding aims [4, p. 30]. As information that is producted and use in own interests subjects of menage yields to influence in the conditions of steady development, it is possible to assume existence of such influence directly on the criterion of her evaluation.

The results of the study allow us to solve the theoretical problem of systematization and algorithmization of the process of forming audit procedures that can be used by the auditor to evaluate information. At the same time, at the practical level, these results will allow the auditor to adequately assess the content of interests and expectations of users of the results of their work, which will improve the quality of its work.

\section{Джерела та література}

1. Жук В. М. Наукове означення інституціональної теорії бухгалтерського обліку (на засадах ідеї сталого розвитку). Збірник наукових праџь ПДАТУ. 2009. Вип. 17. Т. 2. С. 139-146.

2. Шерстюк О. Л. Зміст та природа потреб користувачів фінансової інформації. Вісник Житомирського державного технологічного університету. Серія: Економічні науки. 2016. № 3(77). С. 39-45.

3. Кочерга М. М. Ефективність екологічного менеджменту в сільському господарстві. Агросвіт. 2013. №6. C. 29-33.

4. Мельник К.П. Формування критеріїв оцінювання під час аудиту в умовах сталого розвитку. Економічний часопис СНУ імені Лесі Украӥнки. 2019. Вип. 2 (18). С. 115-121. 


\section{Referances}

1. Zhuk V. M. (2009). Naukove oznachennia instytutsionalnoi teorii bukhhalterskoho obliku (na zasadakh idei staloho rozvytku) [Scientific definition of the institutional theory of accounting (based on the idea of sustainable development)] Zbirnyk naukovykh prats PDATU. No. 17. Pp. 139-146. [In Ukrainian].

2. Sherstiuk O. L. (2016). Zmist ta pryroda potreb korystuvachiv finansovoi informatsii. Visnyk Zhytomyrskoho derzhavnoho tekhnolohichnoho universytetu. [The content and nature of the needs of users of financial information]. Seriia: Ekonomichni nauky No. 3. Pp. 39-45. [In Ukrainian].

3. Kocherha M. M. (2013). Efektyvnist ekolohichnoho menedzhmentu v silskomu hospodarstvi [The effectiveness of environmental management in agriculture]. Ahrosvit. No. 6. Pp. 29-33. [In Ukrainian].

4. Mel`nyk K.P. (2019). Formuvannya kryteriyiv ocinyuvannya pid chas audytu v umovax stalogo rozvytku [Formation of evaluation criteria during the audit in the context of sustainable development]. Ekonomichny` $\mathrm{j}$ chasopy`s SNU imeni Lesi Ukrayinky`. No. 2 (18). Pp. 115-121. [In Ukrainian].

Стаття надійшла до редакції 20.08.2019 р. 